Article

\title{
(Re)Searching with Imperial Eyes: Collective Self-Inquiry as a Tool for Transformative Migration Studies
}

\author{
Madeline J. Bass *, Daniel Córdoba and Peter Teunissen \\ MOVES EJD, Faculty of Humanities and Philosophy, FU Berlin, 14195 Berlin, Germany; \\ E-Mails: madeline.bass@fu-berlin.de (M.J.B.), daniec78@zedat.fu-berlin.de (D.C.), p.teunissen@fu-berlin.de (P.T.) \\ * Corresponding author
}

Submitted: 15 June 2020 | Accepted: 10 August 2020 | Published: 19 November 2020

\begin{abstract}
Migration scholars, and the universities and institutions who fund them, at times neglect to address the ways in which the traces of the imperial past, and references to the 'post' colonial serve to obfuscate and legitimize discriminatory practices in their work. The 'imperial eyes' of the academy set the terms and limitations on interactions, locations, and relationality in research, reducing the agency of migrants, producing stratified configurations in the positionality of both migrants and researchers and, subsequently, exacerbating dynamics of exclusion and extraction. As early-stage researchers, we see a critical need for an approach to migration studies which undermines the ongoing impact of colonialism and the normativity of institutionalized, hierarchical narratives that haunt academia. Our research builds on the work of scholars who write about the autonomy of migration, liberation theorists, and critical Indigenous perspectives, but our positions are also influenced by those on the 'frontlines' resisting various manifestations of violence and exclusion. In this article, using an interdisciplinary model, we propose the notion of collective self-inquiry to critically question and inquire into our own methods and approaches and provide a set of methodological tools that can be applied by other researchers within and outside of the university. These tools invite us to work collectively and look more critically at the b/ordering of movement(s) across former empires, thus helping us navigate towards the undercommons, a place where the liberatory potential of the academy can be realized.
\end{abstract}

\section{Keywords}

imperial eyes; collective self-inquiry; migration studies; neoliberal university; post-colonialism; undercommons

\section{Issue}

This article is part of the issue “Method as Border: Articulating 'Inclusion/Exclusion' as an Academic Concern in Migration and Border Research in Europe" edited by Kolar Aparna (Radboud University, The Netherlands), Joris Schapendonk (Radboud University, The Netherlands) and Cesar Merlín-Escorza (Radboud University, The Netherlands).

(C) 2020 by the authors; licensee Cogitatio (Lisbon, Portugal). This article is licensed under a Creative Commons Attribution 4.0 International License (CC BY).

\section{Introduction}

Jodi Byrd, writing about the 'transit of empire,' describes a conversation she had with her late father (Byrd, 2011). "We [Indigenous peoples] didn't have time, money, or power," he tells her (Byrd, 2011, p. xii). And though Byrd, a Chickasaw writer and academic, wants to argue back, to talk of negotiations and resources, she eventually finds that there is something fundamentally true in his words, particularly within academic, literary, cultural, and political figurations (Byrd, 2011, p. xii). Turning to this research collective, the authors of this article, and our place in the academy, the circumstances could not be more different. None of us are Indigenous, two of us come from former colonial empires, and the third was raised in a settler colonial state. Though we dedicate our time, money, and power to community organizing and activism work, as doctoral students at our prestigious, internationally-known universities, working for a European Union-funded Horizon 2020 Project, riding the waves of the 'migration industry' (Andersson, 2014; Cabot, 2019; Cranston, Schapendonk, \& Spaan, 2018), 
and as EU citizens, these three resources (time, money, and power) remain readily available to us. This privilege situates us often in contrast with the migrants and people in transit who we work with. But to what ends? How do we spend our time, what do we do with our money, and are we willing to share any of our power in this pursuit?

Power and privilege are hallmarks of western academia, a historically elitist institution that looks through 'imperial eyes,' producing research through which "the underlying code of imperialism and colonialism is both regulated and realized" (Smith, 2012, p. 8). The imperial eyes of the academy set terms and limitations on interactions and make claims of sterile objectivity and neutrality in research which diminish the agency of migrants, produce stratified configurations, and, subsequently, exacerbate the dynamics of exclusion in these relationships. In the context of EUrope, research justifies and propels forward discrimination and Eurocentrism. As EUrope fuels chaos and conflict around the world (Akkerman, 2016, 2018), people move through the securitized, selective, and deadly EUropean migration regime(s) (Papadopoulos, Stephenson, \& Tsianos, 2008). The "waiting, detention, relations, suffrageand even deaths-have become a profitable business" (Franck, 2018, p. 201) and knowledge production is one branch of this industry (Cabot, 2019). In 2017 alone the European Commission announced that they had reserved EUR 200 million, to be used from 2018-2020, for research proposals that would predict and manage migration flows and "tackle migration challenges" (European Commission, 2017). It is from this fund that we as early-stage researchers 'enjoy' our paycheck.

The imperial eyes of Europe are well-funded, rigid, and restrictive. As early-stage researchers with liberatory intent, we must seek to challenge the normativity of institutionalized, colonial narratives, and the 'b/ordering' of movement(s) of people across former empires (van Houtum \& van Naerssen, 2002). Given these challenges, is our intended decolonial vision sufficient, or are we actually undertaking research with “imperial eyes?" (Smith, 2012). Our positions are problematized by our inability to reside solely in spaces of struggle, the frontlines that are the beginnings of decolonial space, requiring upkeep and radical inclusion in order to counteract the differential inclusion of migration regimes (Ahmed, 2000; Casas-Cortes et al., 2015; Mezzadra \& Neilson, 2014; Papadopoulos \& Tsianos, 2013). The work of this upkeep, a labor of love, is made more difficult by the violent power of the university institution, but it is not foreclosed altogether.

We will begin this article by outlining some of the essential theoretical frameworks for our research and the methodological tools we used. This will be followed by selected passages from our researcher vignettes, created during focus group sessions. This research model was inspired by the work of Indigenous scholar Madeline Whetung (Nishnaabeg) and non-Indigenous academic Sara Wakefield and their collective reflection (Whetung
\& Wakefield, 2019). The academic institution is only one branch of empire, and our research is only a few lines on one grant-funded project embedded within the billions of euros dedicated to researching migrants and their movements. But rather than being an instrument for migration management within the colonial context of EUropean migration (Gutiérrez Rodríguez, 2018; Saucier \& Woods, 2014), we are attempting to model a research design that takes tools from the research institution (e.g., funding, infrastructures, methodological frameworks), and uses them for liberatory purposes. This article is a discussion of how we aim to engage with research, as operationalized through our collaborative approach. We use collective self-inquiry in order to undermine the academy's imperial eyes, which produce stratified configurations in the positionality of migrants and researchers, while exacerbating hierarchies within the university. This method helps us instead to move, together, towards a university space that refuses the divisive forces of academia. As we aim to demonstrate in this article, collective self-inquiry allows us to detect and undermine our position within the migration industry by moving together towards a more liberatory practice of doing research. We hope that our reflection, presented in this article, will be helpful for other collectives and researchers who want to work within and alongside academia.

\subsection{Who We Are/Where We Stand}

We are all classifiable as economic migrants, and despite our transnational and liberatory intentions EUrope continues to force itself to the forefront of our research, our relationships to its imperial practices adding a necessary politicization to our work. From teaching in Oromia, to working in social struggles in Madrid, and with grassroots organizations across the Mediterranean, each of the researchers has been navigating, subverting, and grappling with imperial legacies that haunt Migration Studies today. There are some significant differences in our approaches to research and our call to work with a liberatory methodology. Daniel has worked as a migrant and with migrants across EUropean space as a researcher and political activist, while expanding on solidarity practices that cross North and South. Peter took his research to the borderlands of this EUropean space to uncover its violent $\mathrm{b} /$ ordering practices, contesting both the migration (knowledge) industry and his position within it. Both beyond and despite these borders, Madeline has been struggling against the afterlives of imperialism that displace Black diasporic peoples in the academy and the metropole. Despite our differences, we share a commitment to producing research that pushes towards political change and refuse to accept our privilege without attempting redistribution or redress.

In an attempt to redefine the procedures of academic production we have included a series of what we call 'interludes' drawn from our recorded group conversa- 
tions, which have an important function both within the scope and structure of this specific article and as part of the larger methodological process we are proposing (for more information see Section 3). Pairing more stylized academic writing with the interludes, which are rawer and more organic, works to humanize and bring life into our article. Along this same vein, the interludes serve to make more clear not just the end result of collective self-inquiry as a practice, but also in a very practical sense, to elucidate the ways in which the process was carried out, and the passionate, sometimes messy backstory behind collective work. As a whole, this article is an exploration of the academy's potential for liberatory practices through the development of alternative methodologies which emphasize community, affinity, and shared knowledge.

\section{Interlude: From the focus group}

Having the conversation this organic way, without having access to theory and cites and all that...it might be something interesting to consider.

\section{Theoretical Background}

The university is an institution which uses research as a management tool, as conceptualized by la paperson, Stefano Harney, Fred Moten, and countless others. The university that la paperson describes runs on "desires for a colonizer's future" while, paradoxically, containing resources that can be rearranged to build a subversive, decolonial alternative (la paperson, 2017, p. xiii). As a research collective we hope to reassemble scraps from the colonial machine, as la paperson $(2017$, p. 53 ) would say, or steal some time, money, and power from the university (after Harney \& Moten, 2013, p. 26). We aim to challenge the imperial logic of western academia by developing relations of cooperation with our colleagues and the people we engage with, based on reciprocity. In the undercommons of this university, what hooks (1984) famously called the margin, there is the opportunity for particular types of liberatory relationships that co-opt and subvert imperial ways of using time, money, and power. This undercommon sensibility refuses the extractivism of the academy.

In defining western academia, it is crucial to acknowledge both its oppressive effects, and the transformative potential it contains. la paperson's notion of the first, second, and third university is useful to conceptualize this behemoth, its violent tendencies, and the ways in which we can undermine its operations for more liberatory ends. The first university is in an intimate partnership with military, capitalist neocolonial industrial complexes (Kumar, 2017; la paperson, 2017, p. 37). It produces knowledge that justifies particular post-empire forms of governance, it is involved in the formation of subjectivities which reproduce socio-economic imbalances rooted in colonial domination, it funds researchers and disciplines with colonial tendencies, and it uses the academic machine to maintain global societal hierarchies (see also Mann, 2008; Spillers, 1987; Tuck \& Yang, 2012). For example, a recent study shows how European universities and major security and defense companies have longstanding relations "in terms of supporting graduate programmes, sponsoring students, funding research programmes, adopting research findings of academics and making it marketable" (Kumar, 2017, pp. 131-132). The first university uses imperial eyes to frame certain migrants and people on the move as 'problems' (Casas-Cortes et al., 2015), while framing other migrants as workers that supply the EUropean economy with its needed workforce (European Commission, 2015; Mezzadra \& Neilson, 2014). Alongside this framing, EUropean research funding is directed towards the defense industry to develop border control technologies (European Commission, 2016) and to conduct research that aims to create institutional and so-called "global solutions" to the "refugee-crisis" (European Commission, 2017). First university positionalities have created the dominant framework for conducting research within the field of Migration Studies, producing knowledge that has emerged from environments where logics of extractivism and elitism (as argued by Cabot, 2019; Sukarieh \& Tannock, 2019) are prioritized.

This brings us to what la paperson describes as the second university, a site of critique, which although important to generating conversation, lacks real action. The second university is held back by a "hidden curriculum" (la paperson, 2017, p. 42) that sets the terms and limitations of interactions, locations, and the so-called sterile objectivity and neutrality of research. This serves, even if inadvertently, to reduce the agency of migrants and produces stratified configurations that exacerbate the dynamics of exclusion in these relationships. We are currently part of the MOVES European Joint Doctorate, an EU/Horizon 2020/Marie Curie Scholarship-funded program, located within both the first and the second domain that la paperson describes, with listed intentions around policy development but no guarantee that these critiques will produce the real, necessary change that makes this world more liveable (see also Sharpe, 2014; Walcott, 2019). This lack of concrete action is part of "a generosity [that] is afforded to white European male theorists for accomplishing work in an area (namely, race/gender) for which they have no documented commitments or track record for engaging" (King, 2015, p. 131). In our collective, Daniel and Peter, as white European male researchers working with migrating peoples, need to give critical attention to their own positionality, or risk recreating the imperial eyes of the first university (Smith, 2012). Critiques of a similar phenomenon can also be found in the work of Goldman (2005) and Cabot (2019), both pieces reminding us of the necessity of keeping research under scrutiny.

Contrasting with these formations, la paperson's (2017, p. 44) third university is a strategic space of hope, 
futurity, and possible liberation, composed of members of the university who refuse to abandon their communities, ideologies, and decolonial intentions in their academic work. The third university is not restricted to the academic setting and its researchers, who too often become trapped within and between the first and the second university. Instead, we move towards the third university in community practices and activist organizing, alongside our work in the university. Following Harney and Moten $(2013$, p. 26), when we work towards the third university we enter "into the underground, the downlow low-down maroon community of the university, into the undercommons," a collective space of enunciation and action. Though the academy works to individualize and isolate us, the undercommon sensibility encourages collective work that brings our different worlds together. The third university engages in transformative praxis alongside and with commitment to marginalized peoples to produce "knowledges part of, and tools for, social and political struggle" (Garelli \& Tazzioli, 2013, p. 246). Groups like Border Monitoring, Super Futures Haunt Qollective, Asylum University, and the research done by Bejarano, Juárez, Garcia, and Goldstein (2019) are examples of partnerships working alongside, within, and beyond the academy in their research endeavors.

Interlude: From the focus group

The university, the academic setting, they produce questions about my research, but I have my own questions. (February 2020, Berlin)

I like that you were asking questions about positionality, about power relations, about how to escape these imbalances of power that are a part of who we are, and being located where we are. (March 2020, Berlin)

\section{Methodology: When the Researcher Becomes the Researched}

Given these theoretical reflections, we seek to provide tools through which other people embedded in academia can better conduct research that moves to the reconciliatory space of the third university. This has led us to collectively turn the gaze onto ourselves, critically questioning our methods and our relationships with our participants, and ultimately, to develop this process of collective self-inquiry. When we started shaping this research process, we were unaware of the precise form it would take. Throughout the process we thus drew on several specific methodological tools, which make it replicable for a broad audience across (and despite) the university and provide a practical approach to engage with 'the field.' We will outline a few of these, briefly, here.

As mentioned above, Madeline Whetung (Nishnaabeg) and Sara Wakefield, an Indigenous MA student and a Geography Professor who recorded and transcribed their discussions, provided us with a model to structure our conversation (Whetung \& Wakefield, 2019). In their methodological approach, they engage in a fruitful dialogue in order to unmask how marginalized positionalities face oppressive relations that are often hidden behind 'ethical' research protocols. It was through their conversation that they were able to come up with collective answers to undermine those conditions, which would have otherwise remained inaccessible to them. Similarly, Aparna, Kramsch, Mahamed, and Deenen (2017), who are in the academy and the frontlines, used the conversationality of their research 'vignettes' to bring individual experiences into collective biographies. Their work elucidated the shared struggle of the fight for "intellectual space in refugee camps," moving knowledge beyond the borders of academia (Aparna et al., 2017, p. 436). We borrowed the notion of a research vignette to illustrate previous research experiences and how they intersect with our own backgrounds to shape our research.

In all of the pieces discussed above, despite their divergent approaches, we may identify a shared affinity for undercommon, third university work. Rather than emerging based on shared disciplinary or methodological concerns, these affinities, as we call them, were the origin point of our collective. Affinities create "natural invitations" to participate and might be described as a "true act of love" (C. Merlin, personal correspondence, 28 May 2020). These affinities are shared views that emerge and show themselves in academic work, daily lived experiences, and even in the more mundane aspects of the ways we live and build community. Because our research collective was built from inside the larger academic institution, we sought to combine our strengths and mitigate some of our weaknesses using a collective process of self-inquiry.

Collective self-inquiry is a methodological tool that critically questions our own methods and approaches, inviting us to work collectively and better understand the b/ordering of movement(s) of people across former empires. In practice, we used collective self-inquiry to question our positionalities and privileges, discuss and analyze the impacts of these imperial eyes within our work, and counteract these tendencies. In more methodological terms, collective self-inquiry may be thought of as a heuristic model that could help us to identify the traces of the imperial past, and uncover the discriminatory practices in our work. Because of its collective character, this approach undermines the constraints and individualizing tendencies that academic institutions impose upon those navigating their complex waters (Gill, 2010; Nash \& Owens, 2015). In this regard it differs from self-reflection broadly defined by feminist scholars (Sultana, 2007) and autoethnography as selfinterview (Crawley, 2012), as it does not centralize the individual in the analysis. Instead, in our approach, collective self-inquiry follows the discussion of pieces like Whetung and Wakefield (2019), Kumsa, Chambon, Yan, 
and Maiter's (2015) conversation on the messiness of group reflection, and the notion of dialogical ethnography (Butler, 2009; Group FIC, 2005). All of these groups use shared reflective questioning and analysis to emphasize how dialogue and discussion shape and change positions. From this perspective, collective self-inquiry can be an important tool for those people engaging with collective practices of knowledge production, participatory action researchers (Del Vecchio, Toomey, \& Tuck, 2017), and other researchers in academia who want to navigate towards more liberatory, undercommon research practices.

To accomplish our collective self-inquiry approach we organized three micro-focus groups where we discussed our theoretical frameworks, research experiences, and positionalities. These focus groups were held in our office, a shared space and 'neutral' ground where we each felt comfortable. Each group meeting was recorded, and these recordings were uploaded to a shared digital drive. The key element of these focus groups, embedded throughout, was the sharing, mutuality, and sociality of their operation. Focus groups run the risk of replicating the divergences between researcher and research population in the process of collecting data (K. Aparna, personal correspondence, 2020). Our focus groups undermined this tendency by distributing power and voice equally and consensually, and positioning the group as a subject which demanded inquiry. The other crucial aspect of these groups was an attempt to build a shared language and foundation of knowledge regarding the complex and sensitive issues we sought to approach, including borders, migration, movement, transnationality, diaspora, and the way these elements are read and written in the academy. In the collective biographical practice of Gannon et al. (2015, p. 192), this process is called the creation of a shared "conceptual apparatus." For our work, shared language included theoretical understandings as well as a collective interpretation of particular terms. What Daniel describes as resistencia, Peter may name as verzet; both words speak to the transformation of the inhuman, and all three of us feel in them the burning need for change. The process of putting these understandings in conversation with each other was a way of building theory as well as working on the specifics of our methodological praxis within the academy.

In the first phase of the research, during the groups discussed above, we shared ideas that influence our research and politics. Selecting these concepts allowed for each individual in the collective to connect their current work and research practices to the outside knowledge of their lived and affective experiences (Ewing, 2018). During these discussions we reflected upon issues of positionality and power relations in order to build a collective narrative. The second phase represented the core of our collective work, where we wrote vignettes about our personal backgrounds, and analyzed these with our individual theoretical lenses. This connected our singular histories with the foundation of collective knowl- edge that we produced in the previous phase. We recorded and transcribed our work sessions and incorporated the ideas and frictions that grew out of these meetings back into the article through the interludes and the vignettes. The vignettes and analysis shared here are a written and condensed version of our conversations.

Interlude: From the focus group

We live in a white supremacist world. I can be a little more subtle about that but I'm not gonna pretend that there are class differences when it's white people on top.

(overlapping voices in response)

\section{Vignettes: A Critical Take on Research through Lived Experiences}

The following excerpts come from our researcher vignettes. In reading the vignettes, the reader is encouraged to notice a few essential ideas, growing from our earlier discussion of the first, second, and third university, and the way these formations take shape in our lived experiences and research practices. These themes relate more generally to community, reciprocality, and intentionality. In addition to being central organizing ideas for this article, the concepts are demonstrative of the imperial eyes of the academy, and the risks of migration research. We include excerpts from the vignettes here as a possible step for other scholars to follow within the larger practice of collective self-inquiry.

\section{Vignette-Madeline}

I made an Addis Ababa taxi driver cry in 2016, a few weeks after Irreecha, the Oromo Thanksgiving. It started with a series of questions. Informal questions, back and forth, occasionally locking eyes in the rearview mirror. I can speak Afan Oromo, his mother tongue, but I'm a Black American. He asks me how I learned the language, what I'm doing there, how I like it. I tell him I live in a village, out West. I'm teaching 9th grade, but I'm also a student, getting my M.S. in Sociology. I'm in the city because I have to be in the city, because the governments I work for have decided the village is no longer safe. 250 Oromos were killed a few weeks ago, just an hour south of here, while celebrating Thanksgiving [see Human Rights Watch, 2017]. We don't need to talk about that to talk about that. Instead I ask him - Where did you grow up? When did you move to the city? How do you like it? 250 Oromos were killed, an hour south of there, just a few weeks before; this is where he grew up, it is why he moved to this city, it is something he can't like, can't be fine with, but must. I think about being in America and seeing another police killing of another Black boy, of 'our' Black American president drone striking Somalis, of 
our staggering inability to make up for those wounds. This is fall of 2016, in Ethiopia's capital city and I'm supposed to be doing research for this master's thesis about Oromo lives in a settler colonial state. Instead, in the taxi, we whisper to each other haa jabaanu, let's be strong, and suuta suuta, slowly change will come. Maybe if he tells this story, it is him who made me cry.

Vignette-Daniel

In 2002, I was part of a diverse collective running a squatted social center. El Laboratorio, as it was called, was at the core of the struggles claiming the right to city and rejecting the neoliberal recipes which from the early 90s were organizing life in Madrid, my hometown. El Laboratorio was for me not only a space for political intervention, but also the opportunity to approach theory from a very situated political praxis. Even more, during that time, it provided me with a very strong feeling of belonging. Almost twenty years after this experience, I found myself in a different squat in Barcelona, el Espacio del Migrante, one run by migrant people. Only this time I was not there as an activist, but as a researcher, and I was trying to 'recruit' participants for my master's thesis research. It felt somehow awkward. Sitting around a table with a few other people, I started talking with an experienced activist from Mexico and explaining about my research. He was very receptive and in the end he ended up collaborating with me, but he was also clear that in el Espacio they distrust academic settings, and see the university as an institution more concerned with its own position and with putting the production of knowledge at service of the dynamics of capital reproduction than questioning the structures of domination and inequality that are at its core. The fact that I actually agreed with him did not allow me to feel completely comfortable.

Vignette-Peter

In 2018, less than two years after the implementation of EU-Turkey-statement, I traveled, like many journalists, researchers, NGOs, volunteers, and activists to the Greek/Turkish borderland with both a sense of anger and solidarity. Anger, because the tragedy unfolding at the gateways of Europe is a direct consequence of European policies that opened the internal borders of Europe and gave me the privilege of a 'mobile' Dutch European citizen. Solidarity to support 'migrant/refugees' on their journey and to organize against the violence of European border regimes. I was actively working and collaborating with a group composed of independent volunteers, activists, and scholars who support people in detention and who are pending their deportation, and document the deportation process of Lesvos. One day, during my fieldwork, I was walking around the Olive Grove, the informal encampment of the official Hotspot Camp Moria, when Fawad and Mo, two men from Algeria, invited me for a cup of tea. Like Fawad and Mo, most people who traveled to EUrope from countries that share a colonial history with EUrope were classified with an economic profile, and could be detained and deported based solely on their citizenship. We had been drinking our tea in silence for a few minutes, when a man from Togo joined us. "Why am I here? Europeans came to my country. You took everything and now I am here in this mess," he said, pointing to the surroundings of Moria Camp. While observing my surroundings, I could not do more than silently nod and agree. Although a short encounter, and despite that my research in Lesvos was a practice of solidarity, I know that I may have an active role in constituting and reiterating the relations of power that I critique, and these reflections continue to linger in my thoughts and direct my work as an Early Stage Researcher.

\section{Interlude: From the focus group}

Creation of knowledge is not the most important thing. The most important thing is to support or to show solidarity with people you engage with.

\section{Vignette Analysis}

What follows is a sample from our focus group conversations, rewritten and shaped into a more formally structured analysis. While we built our initial frame around the notion of the imperial eyes and la paperson's first university, particular issues were of more importance in each analysis. In general, we focused on the first university through the lens of accumulation and extraction, operationalized the second through its over-reliance on critique without action, and identified the third in its strategic actions, which build a more liberatory future. When we joined together in critique, these personal stances helped to build a more effective collective assessment. This framework allowed us to analyze and unpack our positionalities in relation to the liberatory work we aim for.

\section{Interlude: Dialogues on the research process}

We still have a lack of clear answers, but I'm not sure it's feasible [to get them]. Maybe we aim instead to pose good questions, and clear questions, and questions that will be able to guide our process of researching.

I disagree. It's not enough to say, hey I have these privileges. You need to make it actionable. You need to say what you're doing about it. Convince us that working to answer these questions is really important to you. 
Not just that you're posing them. That you're really working to solve them. (March 2020, Berlin)

Madeline's vignette is an example of the way liberatory thinking and decolonial desires remain haunted by ongoing forms of imperialism. Throughout much of the vignette, the author is situated in a third space, working with, caring for, even crying alongside the communities that the research is being undertaken with. From this positionality, she describes in clear terms the myriad forms of harm the academy is responsible for, including, most presciently, an over-saturation of white scholars in the industry who refuse to allow her life, and Black diasporic lives, to 'matter,' denying both meaning and corporeal presence. The danger in this focus, though, is relying too much on second university tools to perform action; pointed critique is not always paired with strategic action. Furthermore, and more dangerously, the postempire who is paying for her work is quite clearly its own brutal force, as she links USian state violence in the Horn of Africa to the funding for the education project she is supporting. But it remains unclear how and when this force reveals itself, and if it can be so easily set aside. Reconciling these tensions requires a closer attention to action, and its potential power. It could be argued that Madeline must go beyond focusing on feeling and sharing stories, and take the step of buying "back an acre of settler land" (as she describes it) in order to truly build the liberatory futures that are otherwise only dreams.

Daniel, positions his own experiences as an activist migrant-worker in parallel to his research population. In contrast to Madeline, Daniel worked outside state institutions and aimed for a degree of "militancy" to design research according to a "beneficial and mutually enriching relationships." By developing a "common plane" of difference, Daniel argues for a strategic approach to push for radical, third university-building change, however, it remains unclear how this strategic plane is developed. How does he intend to move from collective organization towards a more just world? Accepting differences is merely one side of the story, how does one relate, reflect upon, and reconsider the power relations that are re-enacted through these differences? In his vignette, Daniel describes himself as a "white, middle-aged, male, university researcher from Spain" in contrast with the "migrant and racialized women working in the domestic sector" he researches. Why is he allowed careful details, while the others are reduced to a vaguely "racialized" other? These ways of framing raise troubling questions about the impact of the first university, even in research taken with liberatory intent. Beyond these shortcomings, Daniel shows a well formulated criticism of the academic and institutional structures that limit the possibilities of transformative research, and quite thoroughly reflects on the implications of his role as researcher. Although Daniel's strategic considerations are important steps to move beyond the boundaries of the second university they are at times entangled with first university thinking, requiring still a more careful analysis of the practices of $\mathrm{re} / \mathrm{b} /$ ordering that are being manifested within the plane of difference.

Peter tries to reconcile his work as a researcher and his aim to turn research as a means for social struggle, despite the risk of "reiterating relations of power" that oppress migrants. In this sense, he attempts to engage in third university practices by considering research as a responsible political action, working to undermine the coloniality of the academic institution and its role in the migration industry, and tackling the power asymmetries that render migrants into objects of research. This practice is undertaken with a clear sense of commitment for social transformation, as Peter describes how he was actively fighting and organizing against the violence of European border regimes. However, a very important aspect of the third university is apparently missing; a personal engagement with the people he is trying to support, and the means to develop and strengthen community ties. Moreover, generalizing terminology, such as the vague framing of 'migrants/refugees,' shows elements of the dehumanizing and extractivist first university he critiques. In this sense, despite its potential, Peter is using tools and thinking that have not yet managed to move fully beyond a second university critical frame.

The vignettes, generally, trigger important and strategic questions about our positions as researchers, the 'imperial eyes' that influence research, and how we engage with the communities we work with. A common concern towards liberation was evident across the analyses, though, as the critiques show, with the benefit of collective knowledge these concerns become sharpened, strengthened, and more effective. Also illuminating are the ways in which migration, movement, and the empires who facilitate them create shifting power positionalities that affect the research process. In Madeline's work the lurking presence of the US empire remained unaddressed, Daniel failed to rigorously or carefully build community in pursuit of academia, and Peter similarly showed an over-reliance on a loosely-defined solidarity that seemed to lack a human element. Through collective work and conversation, each analysis saw opportunities to identify and dismantle the imperializing tendencies of research in the academy, and places where members of the collective were instead in danger of upholding its colonial values as we described previously in the article. The collective self-inquiry we engaged with demonstrates its applicability to the larger work of migration studies; by looking outside of the 'darlings' you build your analysis around, scholars, academic networks, and corpuses that may be firmly situated in particular geographic, epistemological, or scholarly positions, you can better understand the world of people on the move, and the people moving around you. Collective self-inquiry has the ability to mitigate and address these issues by placing value on the lived experience and expertise of the people you share affinities with. 
Closing Interlude: From the feedback sessions

I feel very sensitive about the fact that I have also found the imperial eyes, imperial voice, imperial hands, imperial thoughts in my own academic practices.(May 2020, Nijmegen)

I won't walk out. I'm gonna ask for love. (May 2020, Den Bosch)

\section{Conclusion}

The process of collective writing and work is a timeconsuming, complicated, and extremely rewarding endeavor. Bringing insights gathered from a migrant squat in Barcelona to the camps of Lesvos, and transiting these European ideas to the Oromo struggle in Ethiopia meant finding a shared language for these experiences, and admitting that there may be instances where no such common tongue exists. In each vignette, despite the reflexive work of their crafting and the collaboration that led up to the final product, there were spaces where we misspoke or ignored a crucial piece of the puzzle. In collaboration, these oversights became more visible.

While the university sets the terms and conditions on our contract, our work/lives, and even our subject populations, there are cracks in the foundation of this institution through which more transformative work can take place. Migration studies, as embedded in the larger institutionalized policing of movement, is a field in need of this type of intervention and critical questioning as found in pieces like Aparna and Kramsch (2018), Bejarano et al. (2019), and Del Vecchio et al. (2017). Through practices or techniques such as collective writing, the interview, or the focus group we would like to extend our desire to talk both among ourselves and to others, moving towards a more liberatory practice of academic research. Rephrased, perhaps, there is an element of replicability that we believe connects this project into many other studies in the field of migration and beyond. As Harney and Moten share: "Well, when we are apart we are not alone. We are apart but with others, elaborating on our partnership through others and coming together in different configurations" against the academy's "individuating tools" of "improvement, advancement, recognition" (Ngin, van Horn, \& Westfall, 2020). This description is not intentionally vague, rather it means to show that looking for and building collective networks may be easier than you think. Likely, the foundations of these groups already exist in your office, at the coffee shop, your neighborhood, the classroom, in the writing group you are thinking about joining. Ask yourself: How do you want the world to look? How do you want your hometown, your neighborhood, your school to look? Who do you want to work with, and why? Where are they? What will you bring to the table once you help building it? What is going to be researched and who is making decisions about it? Who is the research work done with? What is going to be asked, and where will the data go? Answer these questions with your colleague, your best friend, your neighbor, and then try once more with the whole group. When you begin your research, ask these questions again.

We believe that asking yourself questions collectively, and engaging in collective self-inquiry, is a powerful tool to navigate towards the undercommons, undermining the structures of precarity inside academia, as well as academia as an institution inside society. However, this is not to say that this approach is without its limitations. Engaging in critique without a plan to action or remaining too insulated in first university accumulation to fully identify these shortcomings are some possible points of weakness. Furthermore, although we position ourselves outside the strict boundaries of academia, our collective self-inquiry, and our primary audience is still all situated within the university. Though Europe is where colonialism was born and learned to thrive, though the universities produced by these imperial states were some of the empire's earliest garrison forces, and despite the fact that they continue to benefit from research as an industry of exploitation, we refuse to let this 'first' university be the only one, or allow research to be part of an academic market that manages our time, money, and power relations with imperial ideologies. We refuse to be cogs in this colonial research machine, and believe that there may be others who want to be reassembled, with third university visions in mind. Let us move together towards a more liberatory and reconciliatory future.

\section{Acknowledgments}

Thank you to Kolar and Joris for the opportunity, and to Cesar for the rich comments and conversation. We appreciate the feedback from the anonymous reviewers. To Melanie, thank you for your inexhaustible support from within the university. The research for this article was supported by the MOVES project, which has received funding from the European Union's Horizon 2020 research and innovation programme under the Marie Skłodowska-Curie grant agreement No. 812764.

\section{Conflict of Interests}

The authors declare no conflict of interests.

\section{References}

Ahmed, S. (2000). Strange encounters: Embodied others in post-coloniality. New York, NY: Routledge.

Akkerman, M. (2016). Border wars: The arms dealers profiting from Europe's refugee tragedy. Transnational Institute. Retrieved from https://www.tni.org/en/ publication/border-wars

Akkerman, M. (2018). Expanding the fortress: The policies, the profiteers, and the people shaped by EU's externalisation programme. Transnational Institute. Retrieved from https://www.tni.org/en/publication/ 
expanding-the-fortress

Andersson, R. (2014). Illegality, Inc.: Clandestine migration and the business of bordering Europe. Oakland, CA: University of California Press.

Aparna, K., \& Kramsch, O. T. (2018). Asylum university: Re-situating knowledge-exchange along cross-border positionalities. In G. Bhambra, K. Nisancioglu, \& D. Gebrial (Eds.), Decolonising the university: Context and practice (pp. 93-107). London: Pluto Press.

Aparna, K., Kramsch, O., Mahamed, Z., \& Deenen, I. (2017). Lost Europe(s). Etnografia e ricerca qualitativa, Rivista quadrimestrale, 3, 435-452.

Bejarano, C. A., Juárez, L. L., García, M. A. M., \& Goldstein, D. M. (2019). Decolonizing ethnography. Durham, NC: Duke University Press.

Butler, U. M. (2009). Notes on a dialogical anthropology. Anthropology in Action, 16(3), 20-31. https:// doi.org/10.3167/aia.2009.160303

Byrd, J. (2011). The transit of empire. Minneapolis, MN: University of Minnesota Press.

Cabot, H. (2019). The business of anthropology and the European refugee regime. American Ethnologist, 46, 261-275. https://doi.org/10.1111/amet.12791

Casas-Cortes, M., Cobarrubias, S., De Genova, N., Garelli, G., Grappi, G., Heller, C., . . . Tazzioli, M. (2015). New keywords: Migration and borders. Cultural Studies, 29(1), 55-87. https://doi.org/10.1080/09502386. 2014.891630

Cranston, S., Schapendonk, J., \& Spaan, E. (2018). New directions in exploring the migration industries: Introduction to special issue. Journal of Ethnic and Migration Studies, 44(4), 543-557. https://doi.org/ 10.1080/1369183X.2017.1315504

Crawley, S. (2012). Autoethnography as feminist selfinterview. In J. F. Gubrium, J. A. Holstein, A. B. Marvasti, \& K. D. McKinney (Eds.), The SAGE handbook of interview research: The complexity of the craft (pp. 143-160). Thousand Oaks, CA: SAGE Publications.

Del Vecchio, D., Toomey, N., \& Tuck, E. (2017). Placing photovoice: Participatory action research with undocumented migrant youth in the Hudson Valley. Critical Questions in Education, 8(4), 358-376.

European Commission. (2015). Communication from the Commission to the European Parliament, the Council, the European Economic and Social Committee and the Committee of the Regions: A European agenda on migration (Document 52015DC0240). EurLex. Retrieved from https://eur-lex.europa.eu/legalcontent/EN/TXT/?uri=CELEX\%3A52015DC0240

European Commission. (2016). Funding \& tender opportunities. Europa.eu. Retrieved from https:// ec.europa.eu/info/funding-tenders/opportunities/ portal/screen/opportunities/topic-details/bes-032015

European Commission. (2017). Horizon 2020 work programme for research \& innovation 2018-2020. Brussels: European Commission, Research and Innovation. Retrieved from https://ec.europa.eu/ programmes/horizon2020/sites/horizon2020/files/ migration_fact_sheet_2018-2020.pdf

Ewing, E. (2018). The quality of the light: Evidence, truths, and the odd practice of the poet-sociologist. In O. N. Perlow, S. L. Bethea, D. I. Wheeler, \& B. M. Scott (Eds.), Black women's liberatory pedagogies (pp. 195-210). London: Palgrave Macmillan.

Group FIC. (2005). Investigación crítica: Desafíos y posibilidades [Critical research: Challenges and possibilities]. Athenea Digital. Revista de Pensamiento e Investigación Social, 1(8), 129-144. https://doi.org/ $10.5565 / \mathrm{rev} /$ athenead/v1n8.223

Franck, A. K. (2018). The Lesvos refugee crisis as disaster capitalism. Peace Review, 30(2), 199-205.

Gannon, S., Kligyte, G., McLean, J., Perrier, M., Swan, E., Vanni, I., \& van Rijswijk, H. (2015). Uneven relationalities, collective biography, and sisterly affect in neoliberal universities. Feminist Formations, 27(3), 189-216.

Garelli, G., \& Tazzioli, M. (2013). Challenging the discipline of migration: Militant research in migration studies, an introduction. Postcolonial Studies, 16(3), 245-249.

Gill, R. (2010). Breaking the silence: The hidden injuries of neo-liberal academia. in R. Flood \& R. Gill (Eds.), Secrecy and silence in the research process: Feminist reflections (pp. 228-244). Abingdon: Routledge.

Goldman, M. (2005). Imperial nature. New Haven, CT: Yale University Press.

Gutiérrez Rodríguez, E. (2018). The coloniality of migration and the "refugee crisis": On the asylummigration nexus, the transatlantic white European settler colonialism-migration and racial capitalism. Refuge, 34(1), 16-28.

Harney, S., \& Moten, F. (2013). The undercommons. Brooklyn, NY: Autonomedia.

hooks, b. (1984). Feminist theory: From margin to center. New York, NY: Routledge.

Human Rights Watch. (2017). Fuel on the fire. Human Rights Watch. Retrieved from https://www.hrw.org/ report/2017/09/20/fuel-fire/security-forceresponse-2016-irreecha-cultural-festival

King, T. L. (2015). Post-identitarian and postintersectional anxiety in the neoliberal corporate university. Feminist Formations, 27(3), 114-138.

Kumar, R. (2017). Securing through technology. EU actors, relations, practices (Unpublished Doctoral dissertation). Brussels School of International Studies, Brussels, and the University of Kent, UK.

Kumsa, M. K., Chambon, A., Yan, M. C., \& Maiter, S. (2015). Catching the shimmers of the social: From the limits of reflexivity to methodological creativity. Qualitative Research, 15(4), 419-436.

la paperson. (2017). A third university is possible. Minneapolis, MN: University of Minnesota Press.

Mann, S. (2008). Study, power and the university. Maidenhead: McGraw-Hill Education.

Mezzadra, S., \& Neilson, B. (2014). Border as a method: 
The multiplication of labour. Durham, NC: Duke University Press.

Nash, J., \& Owens, E. A. (2015). Institutional feelings: Practicing women's studies in the corporate university. Feminist Formations, 27(3), vii-xi.

Ngin, Z., van Horn, S., \& Westfall, A. (2020, May 1). When we are apart we are not alone: A conversation with Fred Moten and Stefano Harney. The Indy. Retrieved from from https://www.theindy.org/2017

Papadopoulos, D., \& Tsianos, V. (2013). After citizenship: Autonomy of migration, organisational ontology and mobile commons. Citizenship Studies, 17(2), 178-196. https://doi.org/10.1080/13621025. 2013.780736

Papadopoulos, D., Stephenson, N., \& Tsianos, V. (2008). Escape routes: Control and subversion in the 21st century. London: Pluto Press.

Saucier, P. K., \& Woods, T. P. (2014). Ex aqua: The Mediterranean basin, Africans on the move and the politics of policing. Theoria: A Journal of Social and Political Theory, 61(141), 55-75.

Sharpe, C. (2014). Black studies: In the wake. The Black Scholar, 44(2), 59-69.

Smith, L. T. (2012). Decolonizing methodologies: Research and Indigenous peoples (2nd ed.). New York, NY: Zed Books.
Spillers, H. (1987). Mama's baby, papa's maybe: An American grammar book. Diacritics, 17(2), 64-81.

Sukarieh, M., \& Tannock, S. (2019). Subcontracting Academia: Alienation, exploitation and disillusionment in the UK overseas Syrian refugee research industry. Antipode, 51(2), 664-680. https://doi.org/ 10.1111/anti.12502

Sultana, F. (2007). Reflexivity, positionality and participatory ethics: Negotiating fieldwork dilemmas in international research. ACME: An International Journal For Critical Geographies, 6(3), 374-385.

Tuck, E., \& Yang, K. W. (2012). Decolonization is not a metaphor. Decolonization: Indigeneity, Education \& Society, 1(1), 1-40.

van Houtum, H., \& van Naerssen, T. (2002). Bordering, ordering and othering. Tijdschrift voor Economische en Sociale Geografie, 93(2), 125-136.

Walcott, R. (2019). The end of diversity. Public Culture, 3(2), 393-408.

Whetung, M., \& Wakefield, S. (2019). Colonial conventions: institutionalized research relationships and decolonizing research ethics. In L. T. Smith, E. Tuck, \& K. W. Yang (Eds.), Indigenous and decolonizing studies in education: Mapping the long view (1st ed., pp. 146-158). New York, NY: Routledge.

\section{About the Authors}

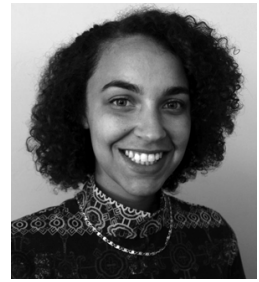

Madeline J. Bass was raised in a settler state, on the border between two colonial empires, descended from immigrants and stolen people. She has a degree in Sociology and Anthropology from Wells College in Aurora, New York, and an M.S. in Sociology from Portland State University in Portland, Oregon, USA. She lived in Western Oromia, Ethiopia, from 2014-2017. Her present work is with Oromo women across the diaspora, focusing on their struggles against structures of violence.

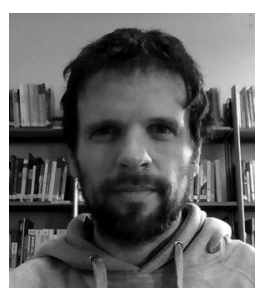

Daniel Córdoba was born and raised in Madrid and has, later on, lived and developed his professional and academic career in different countries. He holds a Bachelor's degree in Geography and History by UNED in Spain and a Master's degree in History, International Relations, and Cooperation by the University of Porto. He is currently researching the processes of collective action of migrant women working on the domestic and care sector in Spain.

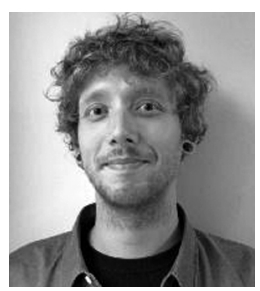

Peter Teunissen obtained a B.S. in Anthropology and Development Sociology and a B.A. in Philosophy from the Radboud University Nijmegen in the Netherlands. In 2017, he was a Research Assistant with the Nijmegen Centre for Border Research where he worked on the relation between vehicles, borders, and migration. In 2018, he graduated from Utrecht University's Gender and Ethnicity Research Master. Since then, he has been working on the intersections of migration industries, b/ordered mobilities, and the infrastructures of exclusion. 